\title{
Changes of Extracellular Matrix of Rat Cornea after Exposure to Hypoxia
}

\author{
G. MAHELKOVÁ ${ }^{1}, J_{\text {KORYNTA }}{ }^{1}$, A. MORAVOVÁ ${ }^{1,2}$, J. NOVOTNÁ $^{2}$, R. VYTÁŠEK $^{2}$, \\ J. WILHELM ${ }^{2}$
}

${ }^{1}$ Clinic of Ophthalmology and ${ }^{2}$ Institute of Medical Chemistry and Biochemistry, Second Medical

School, Charles University, Prague, Czech Republic

Received August 14, 2006

Accepted January 16, 2007

On-line available February 8, 2007

\section{Summary}

The purpose of the study was to check whether hypoxia of corneal tissue increases the collagenolytic activity due to release of reactive oxygen and nitrogen species. Rats were exposed to hypoxia $10 \% \mathrm{O}_{2}$ for 4,14 , and 21 days. The radical tissue injury was measured by the level of nitrotyrosine and changes in the lipoperoxide-related fluorophores. Collagen protein composition was analyzed by slab gel electrophoresis. The activity of gelatinolytic enzymes was studied using the zymography. The vascularization of the corneas was measured. We found no differences in the corneal tissue in the gel electrophoretic profile of collagenous proteins and gelatinolytic activity between normoxic and hypoxic rats. We did not find any sign of radical tissue injury. There were no changes in the vascularization of corneas after exposition to hypoxia. The environmental $10 \%$ hypoxia does not induce radical tissue injury and an increase of collagenolytic activity in the rat cornea.
\end{abstract}

\section{Key words}

Cornea • Hypoxia - Metalloproteinase • Oxidative damage • Nitrotyrosine

\section{Corresponding author}

Gabriela Mahelková, Institute of Physiology, Second Medical School, Charles University, Plzeňská 221, 15000 Praha 5, Czech Republic. E-mal: gabriela.czakoova@post.cz

\section{Introduction}

Corneal metabolism depends on a critical level of atmospheric oxygen. Below this level a series of specific metabolic events occurs (Klyce 1981, Bonanno and Polse 1987). Glycogen depletion and altered adenosine triphosphate concentrations in the epithelium have been described (Thoft and Friend 1975). The lactate level is enhanced (Klyce 1981) due to increased anaerobic glycolysis and altered endothelial transport (Barr and Schoessler 1980). The acute metabolic responses to hypoxia are reversible. However, chronic exposure to low oxygen concentration may induce structural changes in all the cornea layers that may take several months to restore, or they even may be permanent (Polse et al. 1990, Madigan and Holden 1992).

The critical oxygen requirement to avoid structural corneal changes in human is still a debated subject. Exposure to $\mathrm{pO}_{2} 76 \mathrm{~mm} \mathrm{Hg}\left(10 \% \mathrm{O}_{2}\right.$, hypobaric hypoxia) for 30 days showed structural changes in the corneal stroma, neovascularization with advanced vessel differentiation and active vessel proliferation (Mastropasqua et al. 1998).

Hypoxia causes free radical tissue injury that results in biochemical alterations of the extracellular matrix and in extracellular matrix remodeling. The tissue remodeling is probably directly linked to the production of reactive oxygen species (ROS) and other radicals (e.g. NO derived radicals) (Cadenas et al. 1977, Misra and Fridovich 1972, Fried et al. 1973, Herget et al. 2000). The increase in radical production is well documented in exposure to hypoxia (Hampl and Herget 2000). A very reactive substance, peroxynitrite and its derivatives, originate from superoxide and nitric oxide interaction (Muijsers et al. 1997). The increase of nitrotyrosine, the stable product of peroxynitrite reaction within proteins, is 
often used as a marker of peroxynitrite production (Beckman 1996, Beckman and Koppenol 1996). Plasma concentration of nitrotyrosine increases in the first days of exposure to hypoxia (Herget et al. 2000).

Aldehydic products of free radical-initiated lipid peroxidation interact with proteins to form fluorescent compounds with distinguished spectral features. These fluorophores are also used as markers of protein free radical damage (Gardner 1979, Fukuzawa et al. 1985, Wilhelm and Herget 1999, Itakura et al. 2000).

The reactive oxygen and nitrogen species react with the catalytic site of metalloproteinases (Rajagopalan et al. 1996). It was shown that chronic hypoxia initiates an increase in lung collagenolytic activity in rat lungs which results in the presence of low molecular weight collagen type I cleavages (Novotná and Herget 1998, 2002).

The aim of our study was to test the hypothesis that chronic hypoxia of cornea causes an increase in collagenolytic activity, which results in stromal remodeling. The putative role of increased production of radicals during the exposure to hypoxia was tested.

\section{Methods}

\section{Exposure to hypoxia}

Adult male Wistar rats were exposed to hypoxia $\left(\mathrm{F}_{\mathrm{i} 02}=0.1\right)$ for 4 days, 14 days, and 3 weeks in an isobaric hypoxic chamber (Hampl and Herget 1990). Oxygen concentration was continuously monitored and regulated $\mathrm{KOH}$ and soda lime adsorbed $\mathrm{CO}_{2}$ and excess humidity was condensed in a refrigerator and adsorbed by silicagel. Each experimental group had its own control group.

\section{Measurement of perilimbal vascularization}

Six control normoxic rats and 8 rats exposed to hypoxia for 21 days were anesthetized by thiopental and the photographs of their corneas were taken using a slit lamp and the digital camera system. The photographs were analyzed using a computer picture analyzing system. The vessels ingrowth was measured from the limbus towards the center of corneas.

\section{Preparation of the cornea tissue}

The eyes were removed and the corneas were dissected immediately after sacrifying the rats with thiopental overdosing. The central clear part of cornea was used for the experiments avoiding the limbal zone (diameter $4 \mathrm{~mm}$ ). The tissue was cut to small pieces and frozen.

\section{Analysis of collagenous proteins in cornea}

Six rats exposed to hypoxia for 4 days and 6 control normoxic animals, 6 rats exposed to hypoxia for 14 days ( 6 controls) and 6 rats exposed to hypoxia for 21 days ( 6 controls) were used for the analysis of collagenous proteins in the cornea and for the zymography. For the analysis of collagenous proteins, after preparation of the corneal tissue and washing in distilled water, the tissue was pepsinized by 1:10 ratio between the weight of pepsin and dry weight of the tissue in $0.5 \mathrm{M} \mathrm{CH}_{3} \mathrm{COOH}, \mathrm{pH} 2.5$, for $4 \mathrm{~h}$ at room temperature and then for $20 \mathrm{~h}$ at $4{ }^{\circ} \mathrm{C}$ and centrifuged $(8000 x \mathrm{~g}$, $30 \mathrm{~min}$ ) (Novotná and Herget 1998). The supernatant was lyophilized.

Gel electrophoretic separations (SDS-PAGE) of collagenous fraction were performed by the method of Laemli on discontinuous slab gel using $4 \%$ stacking gel and $7.5 \%$ separating gel. Samples were dissolved in a sample buffer in the concentration $4 \mathrm{~g} / \mathrm{ml}$, and $12 \mu \mathrm{g}$ of the collagenous fraction was loaded per line. The collagen type I standard from Sigma was loaded in a concentration of $8 \mu \mathrm{g}$ per line. The electrophoretic separation was run in a Tris-glycine buffer system without reduction in Mini-PROTEAN II Electrophoresis Cell (Bio-Rad Laboratories, USA). The gel was stained for proteins with $0.25 \%$ Coomassie Brilliant Blue R in methanol-acetic acid-water (40:10:50 v/v/v). Destaining was performed with methanol-acetic acid-water (40:10:50 $\mathrm{v} / \mathrm{v} / \mathrm{v})$.

\section{Zymography}

The collagenolytic enzymes from the lyophilized corneal tissue were extracted using the nonreducing sample buffer (1.5\% SDS, $15 \%$ glycerol, $0.025 \%$ bromphenol blue). $50 \mu 1 / \mathrm{mg}$ of the buffer per dry tissue weight was let to extract for $22 \mathrm{~h}$ at $4{ }^{\circ} \mathrm{C}$ and then pure extract was separated on $10 \%$ SDS-PAGE containing $0.1 \%$ gelatin. To remove SDS the gels were washed for $30 \mathrm{~min}$ in $2.5 \%(\mathrm{v} / \mathrm{v})$ Triton X-100 and Triton was removed by washing the gels with distilled water and with incubation buffer (50 mM Tris-HCl, $\mathrm{pH} 7.8,10 \mathrm{mM}$ $\left.\mathrm{CaCl}_{2}, 10 \mathrm{mM} \mathrm{NaCl}\right)$. The gels were then incubated $\left(17 \mathrm{~h}, 37^{\circ} \mathrm{C}\right)$ in incubation buffer. Gels were stained with $0.25 \%$ Coomassie Brilliant Blue $\mathrm{R}$ in methanol-acetic acid-water $(40: 10: 50 \mathrm{v} / \mathrm{v} / \mathrm{v})$. Destaining was performed with methanol-acetic acid-water (40:10:50 v/v/v). High 
molecular weight calibration kit (Pharmacia Biotech, USA) was used as standard. The lytic zones were analyzed densitometrically using software for measurements of electrophoregram densities designed by Ing. Jiř́i Semecký, Prague, CR.

\section{Measurement of 3-nitrotyrosine}

Mouse monoclonal antibody NO-60-E3 against 3-nitrotyrosine was prepared in our laboratory. Peroxynitrite was prepared by reaction of acidified solution of $\mathrm{H}_{2} \mathrm{O}_{2}$ with sodium nitrite followed by stabilization of peroxynitrous acid by sodium hydroxide (Koppenol et al. 1996). Standard of nitrated BSA for ELISA was prepared by reaction with peroxynitrite (Beckman 1996).

Highly nitrated proteins were prepared by reaction with $1 \mathrm{mM}$ tetranitromethane (TNM) (Sokolovsky et al. 1966) and reaction was stopped by addition of free tyrosine and subsequent gel filtration on column of Sephadex G-25. 3-nitrotyrosine content of nitrated proteins was determined by difference of absorbance at $430 \mathrm{~nm}$ in acid solution and under alkaline pH (Sokolovsky et al. 1967).

Cornea was minced with scissors and homogenized by sonication four times for $1 \mathrm{~s}(100 \mathrm{~W})$ with $250 \mu \mathrm{TBS} \mathrm{pH}$ 8.4. Extraction was performed for three hours at $4{ }^{\circ} \mathrm{C}$ and after centrifugation supernatants were used for the estimation of concentration of 3nitrotyrosine by inhibition ELISA (described below). Concentration of proteins was done by bicinchonic acid method (Smith et al. 1985).

Method for estimation of 3-nitrotyrosine was slightly modified method of Herget et al. (2000). Briefly, polystyrene 96-well plates (Maxisorp, Nunc) were coated with highly nitrated BSA dissolved in PBS at concentration $5 \mathrm{nM}$ nitrotyrosine. The plates were blocked by three 5 min incubation with PBS plus $0.05 \%$ (v/v) Twen-20 (TPBS). Then $50 \mu \mathrm{l}$ per well of $0.2 \%$ gelatin in TBS pH 8.4 was pipetted and standard solution of nitrated BSA (by peroxynitrite) or tested samples in triplicates were serially diluted. Further $50 \mu \mathrm{l}$ of diluted ascites of our monoclonal antibody NO-60-E3 (1:125 000) in the same buffer was added and mixture was incubated under gentle shaking at laboratory temperature for $90 \mathrm{~min}$. The plates were three times washed with PBS and incubated with $100 \mu$ of antimouse Ig rabbit antibody conjugated with peroxidase (SwAR/Px, Sevapharma, Czech Republic, diluted 1:1000 in $1 \% \mathrm{BSA}$ in PBS) for $90 \mathrm{~min}$. After five washings with

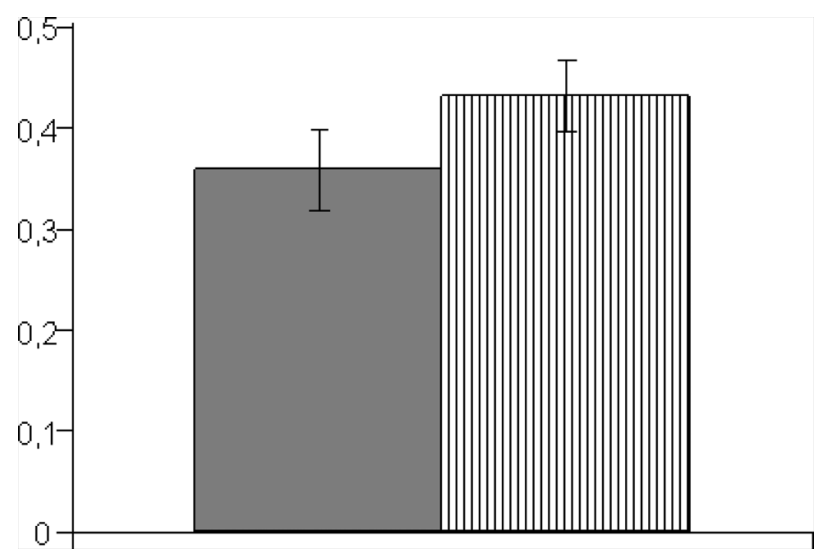

Fig. 1. Perilimbal corneal vascularization of normoxic rats (grey column) and hypoxic rats after 21 days of exposure to hypoxia (shaded column); in $\mathrm{mm}$.

TPBS the plates were developed with o-phenylenediamine and reaction terminated by addition of sulphuric acid. Absorbance was read at $492 \mathrm{~nm}$ using microplate reader. Standard curves and concentration of samples were calculated by Rodbard's four parameters equation (Rodbard and McClean 1977).

\section{Measurement of protein free radical damage}

Five animals exposed to hypoxia for 4 days and 5 control animals, 7 animals exposed to hypoxia for 14 days and 6 control animals, and 6 animals exposed to hypoxia for 21 days and 6 control animals were used. Protein concentrations modified by free radical products were measured on the basis of fluorescent protein adducts in the soluble protein fraction (Gardner 1979, Fukuzawa et al. 1985, Itakura et al. 2000). Briefly, cornea was homogenized in $50 \mathrm{mM}$ phosphate buffer, $\mathrm{pH}$ 7.4, homogenate was cleared by centrifugation (10 $000 \mathrm{x} \mathrm{g}$, $10 \mathrm{~min}$ ) and tridimensional fluorescence spectra were measured in supernatant. The excitation (360 nm) and emission (446 nm) maxima were used for quantitative measurements. The values are expressed in relative fluorescence units (RFU) per mg of protein, determined according to Lowry et al. (1951).

\section{Chemicals}

All chemicals were highest available purity. If not mentioned other the chemicals were obtained from Sigma-Aldrich Chemie GmbH (Diesenhofen, Germany).

\section{Statistical analyses}

The results were statistically evaluated by ANOVA. Differences were considered significant at $\mathrm{P}<0.05$. 


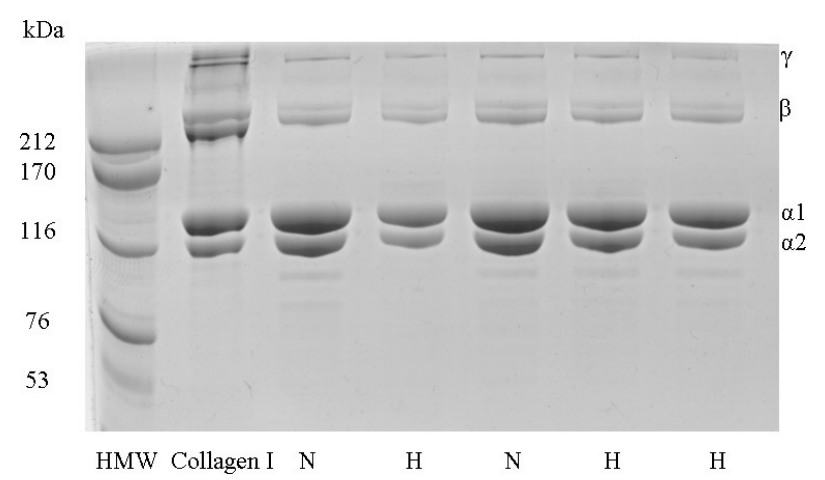

Fig. 2. Gel electrophoresis profile of the collagenous fraction isolated from corneas of rats exposed to normoxic condition $(\mathrm{N})$ and exposed to hypoxia $10 \% \mathrm{O}_{2}$ for 21 days (H); Collagen I collagen type I standard from rat tail (Sigma), HMW - high molecule weight standard (Pharmacia Biotech, USA), $\mathrm{Y}-\mathrm{Y}^{-}$ fraction (chain polymers), $\beta-\beta$-fraction (chain dimers), a1 mixture of individual a1 chains, a2 - a2 chains

\section{Results}

Three-week exposure to hypoxia did not induce an increase of perilimbal vascularization in rats that were exposed to hypoxia for 21 days (Fig. 1).

Similarly, we did not find any differences in collagenous proteins isolated from corneas of hypoxic and control rats. Figure 2 shows a typical gel with collagenous proteins isolated from cornea of control and hypoxic rat (21 days of hypoxia). No differences are apparent. Figures $3 \mathrm{~A}, 3 \mathrm{~B}$ and $3 \mathrm{C}$ show densitometric analysis of electrophoretic profiles of the collagen type I standard and the collagenous fractions isolated from corneas of control and experimental rats exposed to hypoxia for 4, 14 and 21 days. The relative density of the main peaks of collagen chains did not differ significantly. Zymographic analyses of the corneas on gelatine substrate showed lytic zones in the area of active enzyme of gelatinase A (MMP-2) and another lytic zone in the position of $72 \mathrm{kDa}$, that corresponds with the area of the pro-enzyme of gelatinase A (pro-MMP-2). Figure 4 shows typical zymogram of extracts from cornea in control and hypoxic rat (21 days of hypoxia). We did not find significant differences in the density of the lytic zones between normoxic rats and the groups of rats exposed to 4, 14, and 21 days of hypoxia (data not shown).

As a measure of radical injury to corneal proteins we measured the tissue concentration of 3nitrotyrosine and concentration of lipoperoxide-related fluorophores. There was no difference in nitrotyrosine concentration in extracts of corneas of the animals exposed to hypoxia for 4 days, 14 days (data not shown) and 21 days, and the control animals (Fig. 5).

Similarly, there was no difference in the concentration of lipoperoxide-related fluorophores measured in the corneas of the control animals $(0.128 \pm 0.003 \mathrm{RFU}$ (relatives fluorescence unit) per gram) and the corneas of animals exposed to hypoxia for 4 days $(0.127 \pm 0.003 \mathrm{RFU} / \mathrm{g}, 14$ days $(0.127 \pm 0.003 \mathrm{RFU} / \mathrm{g})$, and 21 days $(0.129 \pm 0.002 \mathrm{RFU} / \mathrm{g})$.

\section{Discussion}

Tissue hypoxia is known to induce neovascularization and extracellular matrix remodeling in many organs. Radical tissue injury induced by lack of oxygen probably plays an important role in this process. Cornea, avascular organ, is physiologically supplied by diffusion of oxygen directly from ambient atmosphere. During the eye closure the oxygen comes mostly by diffusion from palpebral conjunctiva. $\mathrm{PO}_{2}$ in conjunctival capillaries is about $60 \mathrm{mmHg}$ and $\mathrm{PO}_{2}$ decreases to approximately $40 \mathrm{mmg} \mathrm{Hg}$ at the corneal surface. Prolonged eyelid closure triggers a cascade of biochemical, cellular and microbial events, culminating in inflammation, hypoxia, and dry-eye states, although significant individual variations in the of open-eye and closed-eye responses to hypoxia were described (Liesegang 2002). The issue of corneal hypoxia is clinically relevant because it is believed that epithelial edema, microcyst formation and decrease in epithelial mitotic rate and neovascularization after contact lenses application results from the reduction of oxygen supply of corneal tissue (Ladage et al. 2001, Donnenfeld et al. 1991). Contact lenses, however, may induce also trauma of corneal surface and some studies document that trauma alone may be responsible for a significant metabolic alteration in epithelial cells and may induce oedema (Thoft and Friend 1975, Čejková et al. 1992). Local hypercapnia and increase of temperature under the contact lens should also be considered (Mastropasqua et al. 1998).

In the present study we addressed the question whether hypoxia in ambient air induces the neovascularization in avascular cornea and remodeling of matrix proteins similar to that which is known from the studies on vascular organs.

We hypothesized that hypoxia induces an increase in production of reactive oxygen and nitrogen species that accentuate collagenolytic activity within the corneal tissue which results in extracellular matrix 

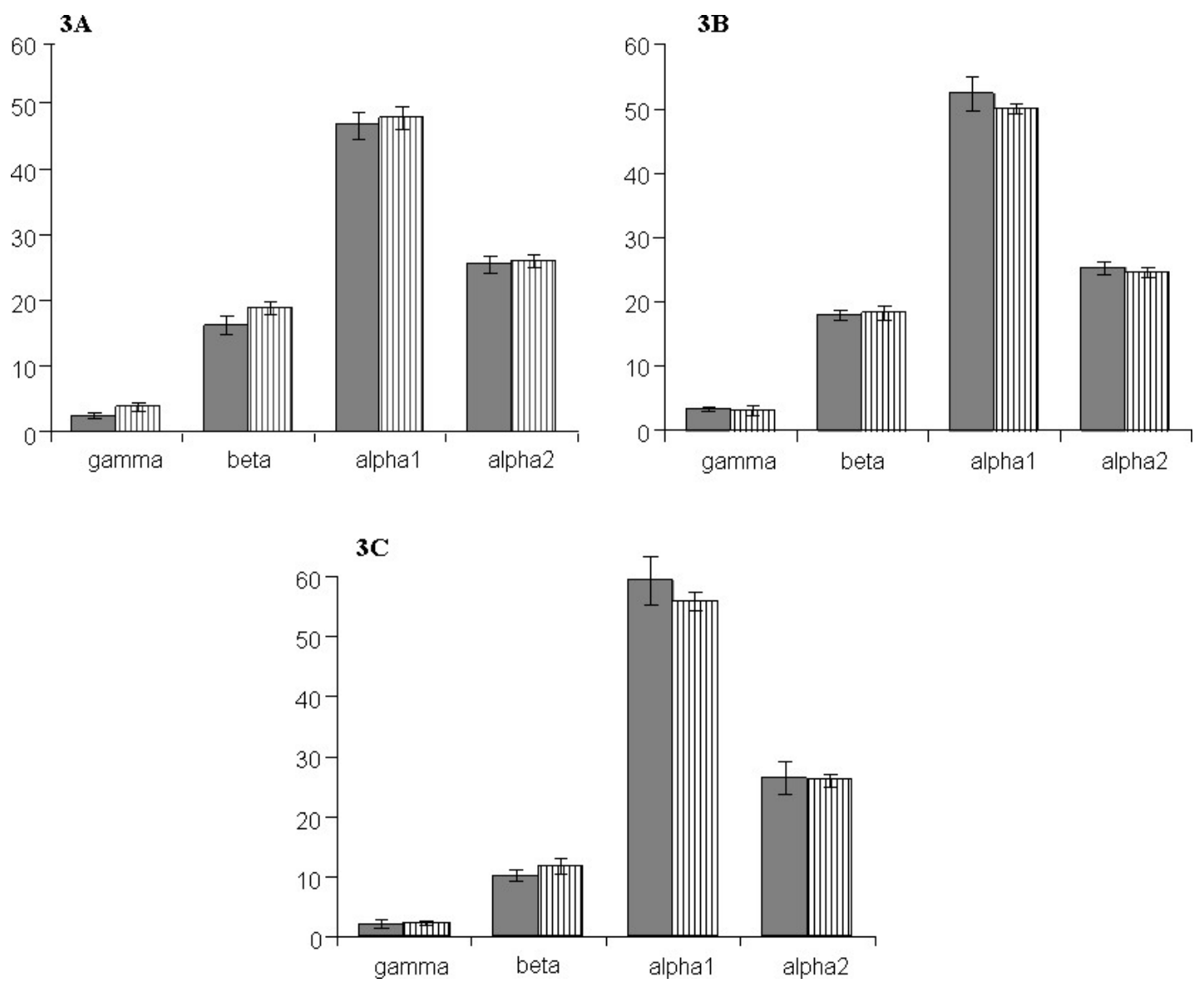

Fig. 3. Relative density of the main peaks separated by gel electrophoresis of collagenous proteins isolated from cornea of animals exposed to 4 days hypoxia (3A), 14 days hypoxia (3B) and 21 days hypoxia (3C); hypoxic animals ( $\mathrm{N}=6$, grey column) and control animals $(N=6$, shaded column); gamma $=\gamma$-fraction (polymers of collagen chains); beta $=\beta$-fraction (dimers of collagen chains); alpha 1 = a1 collagen chains; alpha 2 = a2 chains

proteins degradation (Fini et al. 1998). The extracellular matrix remodeling may then participate in neovascularization of the cornea.

The chronic hypoxia increases production of reactive oxygen species (ROS) (Wilhelm and Herget 1999). It is supposed that the activation of collagenolysis in the early phases of hypoxic exposure is related to the production of radical oxygen species (ROS) and the other radicals. One of the supposed mechanism of activation of MMPs is by non-proteolytic compounds such as ROS or peroxynitrite (Novotna and Herget 2002). We have found no increase in nitrotyrosine concentration (marker of peroxynitrite production (Beckman 1996) and in concentration of lipoperoxide-related fluorophores (the marker of oxidative tissue damage) in the corneas of hypoxic rats.

Stromal extracellular matrix degradation is mediated by a battery of enzymes including matrix metalloproteinases (MMP). MMP-2 (gelatinase A) is responsible for homeostatic remodeling of stroma in normal corneas (Fini et al. 1998, Matsubara et al. 1991). During corneal repair after an injury, other MMPs take part in tissue remodeling and the rate of collagen turnover is much higher. Expression of collagenase and stromelysin is induced within the initiating phase of the repair process after superficial or penetrating injury to stroma in the rabbit model. The activity of gelatinase A (proenzyme and the active form) increases. Collagenase concentration increases within the repair tissue between 1 and 4 weeks after injury and then decreases between 4 and 8 weeks after injury. The expression pattern of other MMPs followed similar kinetics. The activities of collagenolytic enzymes peak at 1 week after wounding and then began decline, but MMP expression is increased even at 7-9 months after wounding (Fini et al. 1998). In a rat model of inflammation-associated corneal neovascularization the MMP-2 mRNA concentration correlates with the development of new vessels (Kvanta et al. 2000). Neutrophils, stromal fibroblast, and epithelial cells were identified as the possible source of stroma-degrading 


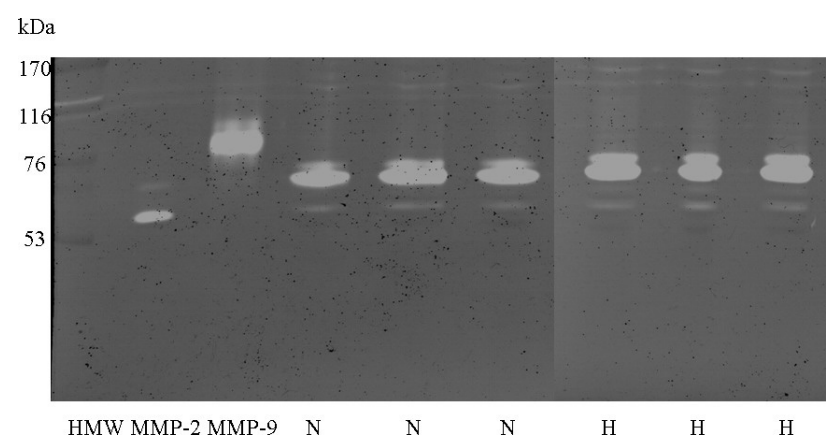

Fig. 4. Zymographic analysis of MMPs extracted from corneas of rats exposed to normoxic condition $(\mathrm{N})$ and exposed to hypoxia $10 \% 02$ for 21 days $(\mathrm{H})$. The lytic zones in the area of active gelatinase A (MMP-2) and in the position of $72 \mathrm{kDa}$ (pro MMP-2); MMP-2 - standard of MMP-2 enzyme, MMP-9 - standard of MMP9 enzyme, HMW - high molecule weight standard (Pharmacia Biotech, USA)

enzymes (Fini et al. 1998).

We have found no difference in collagenolytic activity in the corneas dissected from animals that were exposed to hypoxia and from the normoxic controls in any of the time intervals studied. The electrophoretic profile of the collagenous proteins isolated from the corneas of hypoxic rats was not altered and limbal vascularization or vascularization of the cornea was not enhanced. Exposure to a similar level of hypoxia in the same isobaric hypoxic chamber, however, induces an increase in collagenolytic activity in the lung tissue and peripheral pulmonary arteries which results in collagen type I cleavage (Novotná and Herget 1998). Our results disagree with the findings of Mastropasqua et al. (1998). They described corneal stroma reorganization and Descemet's membrane thickening in corneas of rats exposed to hypoxia $\left(\mathrm{pO}_{2} 76 \mathrm{~mm} \mathrm{Hg}\right)$ for 30 days. Neovascularization with advanced vessel differentiation and active vessel proliferation were clearly detectable in their experiments. They found polymorphonuclears, lymphocytes, and occasional macrophages scattered throughout the corneal stroma. Their findings may therefore be attributed to the presence of corneal inflammation, which may or may not be directly related to tissue hypoxia. We did not perform histologic analysis of the corneas and we cannot comment on the possible presence of some polymorphonuclears, lymphocytes or macrophages within the corneal stroma in our experiments. In addition, the aim of the current study was to analyze the homogenous non-vascular central part of the cornea only. We cannot, therefore, exclude possible hypoxia-induced inflammatory changes in the limbal part of cornea. We did not find any signs of advanced

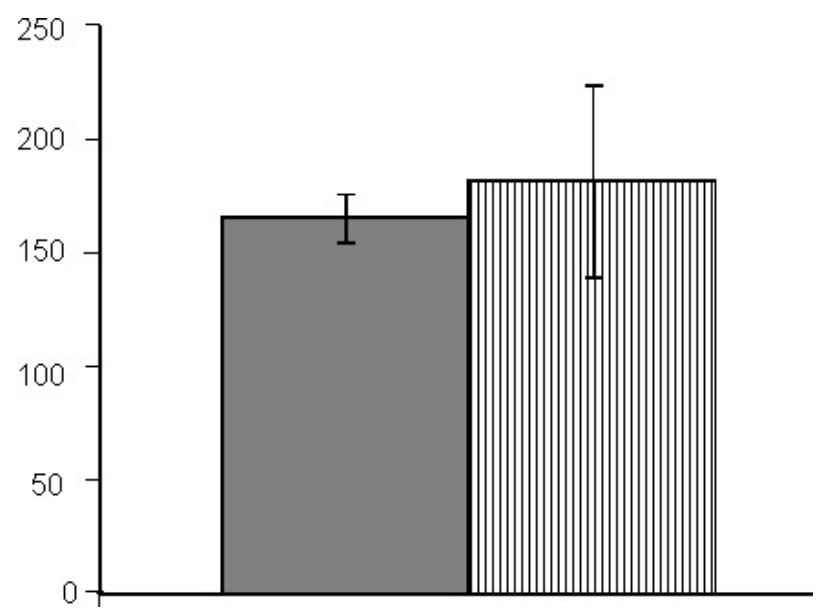

Fig. 5. Nitrotyrosine concentration in the rat cornea after 21 days of hypoxia (shaded column), and in the cornea of the control animals (grey column); in pmol of 3-nitrotyrosine per gram of corneal protein

neovascularization of the hypoxic corneas, the extent of perilimbal vascularization did not significantly differ between the normoxic corneas and the corneas exposed to hypoxia. Therefore, the absence of vascularization of the cornea may explain the difference between absence of collagenolysis in the cornea and rapidly developing collagen degradation in the lung tissue at the same level of hypoxia. The possible gender differences should also be taken in focus because Mastropasqua et al. (1998) found the histological changes in corneas of female Wistar rats in contrast to male rats used in our experiments. The gender difference in susceptibility to tissue hypoxia is well known (Griffin et al. 2000, Zhao and Eghbali-Webb 2002).

We found that exposure to $10 \%$ of oxygen does not induce collagenolysis and angiogenesis in the central cornea. We conclude that hypoxia in ambient air severe enough to induce the lung structural remodeling does not affect collagen tissue proteins in central cornea and does not induce neovascularization. The possible explanation is that the level of hypoxia was not severe enough to induce corneal injury. The same level of hypoxia was efficient in inducing proliferative changes in the lung tissue (Herget et al. 2000, Novotná et al. 2001). The difference between the lungs and central cornea is that cornea remains avascular during the exposure to hypoxia. Therefore we hypothesize that the presence of blood cell releasing radicals is needed to start extracellular matrix remodeling in chronic hypoxia. To prove our hypothesis, it would be interesting to elucidate the effect of hypoxia on the perilimbal part of cornea. We did not study the possible changes of the composition of non-collagen 
extracellular matrix proteins. Changes in production of proteoglycans were described in relation to oxygen tension in different connective tissues including cornea. Keratan sulphate replaces chondroitin sulphate (in terms of tissue concentrations) in condition of poor oxygen supply (Scott 1992). More studies are necessary to elucidate all possible effects of hypoxia on the corneal tissue.

\section{Conflict of Interest}

There is no conflict of interest.

\section{Acknowledgements}

This work was supported by grant No.1763/2001G3 of the Ministry of Education, grant No. NB/6254-3 from IGA Ministry of Health of the Czech Republic and grant No. 305/08/0108 of the Grant agency of the Czech Republic.

\section{References}

BARR JT, SCHOESSLER JP: Corneal endothelial response to rigid contact lenses. Am J Optom Physiol Opt 57: 267274, 1980.

BECKMAN JS: Oxidative damage and tyrosine nitration from peroxynitrite. Chem Res Toxicol 9: 836-844, 1996.

BECKMAN JS, KOPPENOL WH: Nitric oxide, superoxide, and peroxynitrite: the good, the bad, and ugly. Am $J$ Physiol 271: C1424-C1437, 1996.

BONANNO JA, POLSE KA: Corneal acidosis during contact lens wear: effects of hypoxia and $\mathrm{CO}_{2}$. Invest Ophthalmol Vis Sci 28: 1514-1520, 1987.

CADENAS E, BOVERIS A, RAGAN CI, STOPPANI AO: Production of superoxide radicals and hydrogen peroxide by NADH-ubiquinone reductase and ubiquinol-cytochrome c reductase from beef-heart mitochondria. Arch Biochem Biophys 180: 248-257, 1977.

ČEJKOVÁ J, LOJDA Z, VACÍK J, DIGENIS GA, DROPCOVÁ S: Histochemical changes in the rabbit cornea and plasmin activity in the tear fluid during contact lens wear. Favourable influence of protease inhibitors (aprotinin, PC5, elastatinal). Histochemistry 97: 69-76, 1992.

DONNENFELD ED, INGRAHAM H, PERRY HD, IMUNDO M, GOLDBERG LP: Contact lens-related deep stromal intracorneal hemorrhage. Ophthalmology 98: 1793-1796, 1991.

FINI ME, COOK JR, MOHAN R: Proteolytic mechanisms in corneal ulceration and repair. Arch Dermatol Res 290 (Suppl): S12-S23, 1998.

FRIED R, FRIED LW, BABIN DR: Biological role of xanthine oxidase and tetrazolium-reductase inhibitor. Eur $J$ Biochem 33: 439-445, 1973.

FUKUZAWA K, TAKASE S, TSUKATANI H: Fluorescent pigments by covalent binding of lipid peroxidation byproducts to protein and amino acids. Lipids 20: 854-861, 1985.

GARDNER HW: Lipid hydroxiperoxide rectivity with proteins and amino acids: A review. J Agric Food Chem 27: 220-229, 1979.

GRIFFIN M, LEE HW, ZHAO L, AND EGHBALI-WEBB M: Gender-related differences in proliferative response of cardiac fibroblasts to hypoxia: effects of estrogen. Mol Cell Biochem 215: 21-30, 2000.

HAMPL V, HERGET J: Perinatal hypoxia increases hypoxic pulmonary vasoconstriction in adult rats recovering from chronic exposure to hypoxia. Am Rev Respir Dis 142: 619-624, 1990.

HAMPL V, HERGET J: Role of nitric oxide in the pathogenesis of chronic pulmonary hypertension. Physiol Rev 80: 1337-1372, 2000.

HERGET J, WILHELM J, NOVOTNÁ J, ECKHARDT A, VYTÁŠEK R, MRÁZKOVÁ L, OŠŤÁDAL M: A possible role of the oxidant tissue injury in the development of hypoxic pulmonary hypertension. Physiol Res 49: 493$501,2000$.

ITAKURA K, OYA-ITO T, OSAWA T, YAMADA S, TOYOKUNI S, SHIBATA N, KOBAYASHI M, UCHIDA K: Detection of lipofuscin-like fluorophore in oxidized human low-density lipoprotein. FEBS Lett 473: 249-253, 2000.

KLYCE SD: Stromal lactate accumulation can account for corneal oedema osmotically following epithelial hypoxia in the rabbit. J Physiol Lond 321: 49-64, 1981. 
KOPPENOL WH, KISSNER R, BECKMAN JS: Syntheses of peroxynitrite: to go with the flow or on solid grounds? Methods Enzymol 269: 296-302, 1996.

KVANTA A, SARMAN S, FAGERHOLM P, SEREGARD S, STEEN B: Expression of matrix metalloproteinase-2 (MMP-2) and vascular endothelial growth factor (VEGF) in inflammation-associated corneal neovascularization. Exp Eye Res 70: 419-428, 2000.

LADAGE PM, YAMAMOTO K, REN DH, LI L, JESTER JV, PETROLL WM, BERGMANSON JP, CAVANAGH HD: Proliferation rate of rabbit corneal epithelium during overnight rigid contact lens wear. Invest Ophthalmol Vis Sci 42: 2804-2812, 2001.

LIESEGANG TJ. Physiologic changes of the cornea with contact lens wear. CLAO J 28: 12-27, 2002.

LOWRY OH, ROSEBROUGH NJ, FARR AL, RANDALL RJ: Protein measurement with the Folin phenol reagent. J Biol.Chem 193: 265-275, 1951.

MADIGAN MC, HOLDEN BA. Reduced epithelial adhesion after extended contact lens wear correlates with reduced hemidesmosome density in cat cornea. Invest Ophthalmol Vis Sci 33: 314-323, 1992.

MASTROPASQUA L, CIANCAGLINI M, DI TANO G, CARPINETO P, LOBEFALO L, LOFFREDO B, BOSCO D, COLUMBARO M, FALCIERI E: Ultrastructural changes in rat cornea after prolonged hypobaric hypoxia. J Submicrosc Cytol Pathol 30: 285-293, 1998.

MATSUBARA M, GIRARD MT, KUBLIN CL, CINTRON C, FINI ME: Differential roles for two gelatinolytic enzymes of the matrix metalloproteinase family in the remodelling cornea. Dev Biol 147: 425-439, 1991.

MISRA HP, FRIDOVICH I: The univalent reduction of oxygen by reduced flavins and quinones. $J$ Biol Chem 247: 188-192, 1972.

MUIJSERS RB, FOLKERTS G, HENRICKS PA, SADEGHI-HASHJIN G, NIJKAMP FP: Peroxynitrite: a two-faced metabolite of nitric oxide. Life Sci 60: 1833-1845, 1997.

NOVOTNÁ J, BÍBOVÁ J, HAMPL V, DEYL Z, HERGET J: Hyperoxia and recovery from hypoxia alter collagen in peripheral pulmonary arteries similarly. Physiol Res 50: 153-163, 2001.

NOVOTNÁ J, HERGET J: Exposure to chronic hypoxia induces qualitative changes of collagen in the walls of peripheral pulmonary arteries. Life Sci 62: 1-12, 1998.

NOVOTNÁ J, HERGET J: Possible role of matrix metalloproteinases in reconstruction of peripheral pulmonary arteries induced by hypoxia. Physiol Res 51: 323-334, 2002.

POLSE KA, BRAND RJ, COHEN SR, GUILLON M: Hypoxic effects on corneal morphology and function. Invest Ophthalmol Vis Sci 31: 1542-1554, 1990.

RAJAGOPALAN S, MENG XP, RAMASAMY S, HARRISON DG, GALIS ZS: Reactive oxygen species produced by macrophage-derived foam cells regulate the activity of vascular matrix metalloproteinases in vitro. Implications for atherosclerotic plaque stability. J Clin Invest 98: 2572-2579, 1996.

RODBARD D, MCCLEAN SW. Automated computer analysis for enzyme-multiplied immunological techniques. Clin Chem 23: 112-115, 1977.

SCOTT JE. Oxygen and the connective tissues. Trends Biochem Sci 17: 340-343, 1992.

SMITH PK, KROHN RI, HERMANSON GT, MALLIA AK, GARTNER FH, PROVENZANO MD, FUJIMOTO EK, GOEKE NM, OLSON BJ, KLENK DC: Measurement of protein using bicinchoninic acid. Anal Biochem 150: 76-85, 1985.

SOKOLOVSKY M, RIORDAN JF, VALLEE BL: Tetranitromethane. A reagent for the nitration of tyrosyl residues in proteins. Biochemistry 5: 3582-3589, 1966.

SOKOLOVSKY M, RIORDAN JF, VALLEE BL: Conversion of 3-nitrotyrosine to 3-aminotyrosine in peptides and proteins. Biochem Biophys Res Commun 27: 20-25, 1967.

THOFT RA, FRIEND J: Biochemical aspects of contact lens wear. Am J Ophthalmol 80: 139-145, 1975.

WILHELM J, HERGET J. Hypoxia induces free radical damage to rat erythrocytes and spleen: analysis of the fluorescent end-products of lipid peroxidation. Int J Biochem_Cell Biol 31: 671-681, 1999.

ZHAO X, EGHBALI-WEBB M: Gender-related differences in basal and hypoxia-induced activation of signal transduction pathways controlling cell cycle progression and apoptosis, in cardiac fibroblasts. Endocrine 18: 137-145, 2002. 